\title{
THE POLITICS OF HEROES' BODY: ETHNOGRAPHYING THE TRAINING OF FOREIGN ASTRONAUTS IN RUSSIA
}

\author{
Julie Patarin-Jossec (a)
}

(a) Saint Petersburg State University / The Centre Emile Durkheim. Saint Petersburg, Russia / Bordeaux, France. Email: patarinjossec.julie[at]gmail.com

\begin{abstract}
If the literature in the history of the Soviet space program is extremely prolific since the 1960s, including regarding cosmonaut embodiment, a lack remains regarding the contemporary reality of human spaceflight in Russia. As this article discusses, based on interviews and a long-term ethnography of the Russian training of astronauts from Western Europe, North America, and Japan, becoming an astronaut is to develop a legitimate body fitting dominant cultural and gendered models. Three mechanisms serve the manufacture of "heroes" and masculine bodies through the astronaut training: the historical narrative of human spaceflight; the values and virility attributes embed as part of the training; and the instruments used in the daily activity of astronauts (such as spacesuits). This manufacture of a legitimate body, characterized by masculinity and discipline inherited from the past, is a heuristic field for corporality and studies of global politics as it underlines how an interweaving of gender, Soviet heritage, and cultural fantasies frames the bodies of a professional elite.
\end{abstract}

Keywords

Astronaut training; discipline; ethnography; legitimate body; hero; human spaceflight; masculinity; star city; soviet heritage; virility

\section{(c) (1)}

This work is licensed under a Creative Commons «Attribution» 4.0 International License. 


\section{ПОЛИТИКА ГЕРОИЧЕСКОГО ТЕЛА: ЭТНОГРАФИЯ ПОДГОТОВКИ ИНОСТРАННЫХ КОСМОНАВТОВ В РОССИИ}

\section{Патарин-Жоссек Жюли (а)}

(а) ФГБОУ ВО "Санкт-Петербургский государственный университет" / Центр Эмиля Дюркгейма. Санкт-Петербург, Россия / Бордо, Франция. Email: patarinjossec.julie[at]gmail.com

\section{Аннотация}

При огромном количестве книг по истории советской космической программы начиная с 1960-х годов (в том числе и по соматизации космонавтов), мы вынуждены констатировать недостаток в количестве исследований современных реалий полета человека в космос в России.

В данной статье, основанной на интервью и многолетней этнографии российской подготовки космонавтов из Западной Европы, Северной Америки и Японии, говорится о том, что стать космонавтом - значит разработать легитимное тело, соответствующее доминирующим культурным и гендерным паттернам.

Три механизма служат созданию "героических" и маскулинных тел через обучение космонавтов: исторические нарративы о полете человека в космос; ценности и атрибуты мужественности, прививаемые в процессе обучения; и инструменты, используемые в повседневной деятельности космонавтов (такие, как скафандры).

Это изготовление легитимного тела, характеризующегося мужественностью и дисциплиной, наследуемой из прошлого, является эвристическим полем телесности и изучения глобальной политики, поскольку оно подчеркивает, как гендер, переплетающийся с советским наследием и культурными притязаниями обрамляет тело профессиональной элиты.

\section{Ключевые слова}

Подготовка космонавтов; дисциплина; этнография; легитимное тело; герой; полет человека в космос; маскулинность; Звездный городок; советское наследие; мужественность

\section{Это произведение доступно по лицензии Creative Commons «Attribution» («Атрибуция») 4.0 Всемирная}




\section{INTRODUCTION}

Becoming a cosmonaut or an astronaut ${ }^{1}$ means developing a legitimate body fitting dominant cultural and gendered models. That is one of the main conclusions of a research initially started for a $\mathrm{PhD}$ in sociology, resulting in a several-year ethnography in the world of human spaceflight in Russia. As this article discusses, this manufacture of a 'legitimate' body (Boni-Le Goff, 2016), characterized by masculinity and discipline, and the embodiment of cultural heritage, is a heuristic field for a general theory about corporality and global politics, as the training consists of an interweaving of gender and cultural fantasies in an international cooperation context.

On 9 April 1961, the Soviet Air Force pilot Yuri Gagarin becomes the first human being to perform an orbit of the Earth. 572 people ever went to space since then; among them, 64 were women (including fifty Americans and four Russians). Western astronauts and Soviet or Russian cosmonauts who flew in outer space since 1961 consequently perpetrate a relatively homogenous and heteronormative part of the global population: mainly men, white, and heterosexual. Since the late 1990s, the International Space Station ("ISS") is the only human space program for all the space agencies worldwide which detain a human space program (except China). It includes Canada, member-states of the European Space, Japan, Russia, and the United States. Until 2011, Russia and the United States detained transportation systems to convey crews to the ISS. But after the retirement of NASA's Space Shuttle, Russian "Soyuz" vehicle became the only way to launch astronauts and cosmonauts. As a consequence, an important part of the training is managed at the Gagarin Cosmonaut Research and Training Center (Centr Podgotovki Kosmonavtov, imeni $\hat{U}$. Gagarina) located in Star City (Zvezdnyj gorodok, Moscow region, Russia), for all crewmembers regardless their national belonging. The training methods inherited from the Soviet era are regulated by rituals and traditions aiming to maintain a collective memory of the age of Soviet pioneers.

Partly because those rituals and traditions were generated by the first male cosmonauts-mainly Yuri Gagarin-, partly because they aim to celebrate fearless-bravery regard danger and the service to the Motherland, they turn to epitomize the celebration of virile attributes. The profes-

1 'Cosmonaut' is used to refer to Russians, 'Taikonauts' to Chinese crewmembers, and 'Astronauts' to any other nationality. Except when the text directly related to Russians, the term "astronaut" is mostly used in the article as it emphasizes the experience of non-Russian astronauts trained in Russian facilities. 
sionalization of astronauts then relates to masculine attributes; masculinity is thus a process that women astronauts have to embody as well, as part of the docility process. Bodies of women are not exactly disciplined and made docile as bodies of men are, in a social world ruled by power relations among sexes. Feminist sport studies have especially highlighted this dimension: (rough) physical training can serve as a technology of control and power exercise, anchoring women in normative practices (Markula, 2003) potentially accentuating gendered power relationships. Consequently, physical activity requires the embodiment of certain values, representations, and norms that could support a gendered discipline.

The literature in the history of the Soviet space program is extremely prolific since the 1960s and covers various dimensions of the subject. Among these references, a few particularly emphases the role of gender and masculinity in the cosmonaut profession and, more broadly, in the Soviet ideology (Gerovitch, 2015; Jenks, 2012; Fraser, 2017; Kamanin, 19952001 ), or the experience and political significance of women cosmonauts (Sylvester, 2019; Lewis, 2008). In addition to cosmonauts' memoirs, the memoirs of Nikolay Kamanin especially discuss the challenges women faced in the Soviet space program, where the issues of gender and identity regularly appear as constantly interrelated in the training. In the field of media studies, Dario Llinares provided, for his part, rare insights into the gendered embodiment of Western astronauts $(2008 ; 2009 ; 2011)$.

However, this literature remains predominantly historical, hence a lack of researches dedicated to contemporary international training in Russia or based on an empirical method like ethnography. Yet, training astronauts today has not the same reality as in the Soviet Union. Methods and rituals may remain, but the progressive inclusion of international crews from Western Europe, Japan, North America, and even the United Arab Emirates, progressively develop a ground for the global circulation of norms that training in Russia has become. This internationalization of the Russian training (and its related ideal-type of heroism and masculinity) deeply changes the nature of bodies' politics, resulting in possible power struggles and hierarchies between the astronauts, according to their cultural norms and gendered socialization.

The training and the flight acting as rites of passage, astronauts do become national heroes and therefore can exercise a dominant position through their embodiment. Nevertheless, one should not invisibilize that this manufacture of heroes is, first and foremost, a question of invisibilisation of women to the benefit of a model of masculinity based on bodily and mental discipline. As it comes about astronauts, becoming a hero means fitting to virile attributes and, doing so, building a legitimate body. 
In addition to four-and-a-half-year ethnographic fieldwork conducted between August 2015 and January 2020 in European, Russian and Japanese astronaut training facilities (respectively in Cologne, Star City, and Tsukuba), this article is based on interviews with astronauts and cosmonauts from the American, European, Russian, Canadian, and Japanese space agencies. While the profession mainly consists of men, six out of 38 crewmembers interviewed in the field are women. Although interviews cited in this article are anonymized to comply with the ethnographic rules of anonymity ${ }^{1}$, the gender, the flight experience, and the nationality of interviewees are specified in citations throughout the text. However, astronauts from the European Space Agency are only cited as "Western Europeans", since specifying further their nationality would facilitate their identification. Similarly, flight experience remains vague considering that specifying the exact number of space flights would also break away from interviewees' anonymization. If only a few interviews are explicitly cited (often to prevent from identifying the interviewees considering the sore subject of masculine hegemony among crewmembers), this article rather relies on an oral history resulting from the interviews and the immersion in the field during the research time frame.

Without further clarification of the concepts used in this research, it may suggest an essentialization of genders, as bodies, rationalities, and representations of the self uniformly distinct from a "male" standpoint. While considering the appeal to reified men's attributes, one of the risks incurred in taking over the mythologies of masculinity occurring in the astronaut training is to be taken over by those same reified representations. A reflexive analysis of the gendered processes part of the training thus needs to "pay careful attention to masculinity" and its plural forms (Segal, 2008, p. 21) in addressing gender and body discipline, as much as it should critically address the complexity and variations of women's relation to the training. This risk of letting a theoretical frame being plagued by stationary and immutable categories ("men", "women") has been the driving force of many analytical adjustments in the course of feminist theory (see Messerschmidt, 2018). "Masculinity" is far from being a reified category (Connell \& Messerschmidt, 2005) concerning the position of men in a social space structured by power relations, including relationships based on gender--i.e. the "gender order" (Connell, 2005 [1995]). Since these positions are always relational (i.e. "masculinity" only exists as part of a social setting), masculinities are consequently multiple (there is no singular and unique form of "the" masculinity), subject to changes

1 Except one case mentioned in the article, all the interviewees have been anonymized according to their space agency: NASA A, B, Roscosmos A, B, ... for the Russian space agency, and so on. 
through time and space, as well as they are subject to internal contradictions and hierarchies (for a critical review of this literature, see Connell, 2014). Considering "masculinity" as a set of physiological and moral dispositions, invariably embedded through a routinized and ritualized management of the training, avoids taking for granted the social building of gendered identities. Masculinity, constituted with axiological (values) and carnal (body) qualities, remains a permanently pending process.

Like in the army (Higate \& Hopton, 2005) or violent sports (Loirand, 2006; Messner, 1992), it does not seem surprising that women would have to conform to male-dominated standards in the astronaut profession. However, the very way masculinity is exercised and reproduced in the international context of the training (e.g. Western astronauts being trained in Russia according to post-Soviet methods) questions the conditions of the global circulation of cultural gendered norms and the concrete mechanisms of the reproduction of a certain model of masculinity.

As the different sections of this article underline here-after, three mechanisms serve the reproduction of a legitimate and masculine body in the training: historical narrative inherited from Western or Soviet space programs, the moral education of the training, and the standards and instruments used in the daily activity of astronauts. In truth, the historiography of human spaceflight appears to invisibilize women of the profession, emphasizing on cultural construction of space heroes as men. Then, the norms which are embodied as part of post-Soviet rituals followed in the training of international crews in Russia reproduce an ideal of masculinity related to the endurance of pain in the making of heroes. Finally, daily work tools of crewmembers appear as produced according to male body standards, creating difficulties for recruiting and training female crewmembers. The article concludes by discussing the international/national nexus in the development of a hegemonic model of masculinity, as shown in the training in Russia.

\section{HISTORIOGRAPHY: WHEN MASCULINIZATION STARTS WITH AN INVISIBILISATION THROUGH TIME}

Space history witnesses how much the increasing integration of women into the collective corps of astronauts was slow and costly. At the time of "Mercury Seven"-the first seven astronauts recruited by the NASA in 1959: Alan Shepard, Malcolm Scott Carpenter, Walter Schirra (U.S. Navy), Virgil Grissom, Leroy Cooper, Donald Slayton (U.S. Air Force), et John Glenn (U.S. Marine Corps)-, a private selection campaign, entirely feminine, was started by a medical doctor, William Lovelace. Sup- 
ported by the Air Force, this selection led nineteen women to perform the same physical and flight tests than NASA's male candidates. After that the army finally interrupted the access to test facilities, in the absence of official support from NASA, a commission of examination was launched to investigate sexual discriminations in the process. Nevertheless, discriminations based on sex would not be part of the Civil Rights Act before 1964, letting no acknowledgeable illegal behaviors to condemn. NASA did not select women before the late 1970s, and the first female American astronaut (Sally Ride) took off on 18 June 1983.

White, heterosexuals, protestants, and fathers with due diligence (or about to be): that is the portrait serving as a breeding ground to the professionalization of the Western astronaut. The same logic of exclusion was at both sides of the Iron Curtain, whatever the ideology defended by the government. Back in the early phase of the Soviet space program, cosmonauts turned out to perfectly incarnate the project of the New Soviet Man as developed under Stalin: serving the Motherland, disciplined, part of a system exceeding individualities. In other words, cosmonauts were "ideological prototypes" whose achievements allowed the Soviet population to "develop a sense of what living under communism could look like" (Bergman, 1998)1. "Discipline" was then mainly related to the "regular military man's qualities" (Gerovitch, 2015, p. 53): in 1959, selection criteria used for the first group of cosmonauts included "assiduousness, self-discipline, and the unwavering determination to reach the set goal" (id.). Thus, qualifications and properties that cosmonauts were led to develop were not their mastery of the engine, but rather their ability to make their body docile to the vehicule. Height and weight consequently became essential traits of selection while the bodies of cosmonauts fit the machine, rather than the machine fit to the bodies of cosmonauts selected according to other skills and abilities. These criteria are still current, while engineers tend to be promoted among STEMs ("Science, Technology, Engineering, and Mathematics") educational background-where women are already a minority. During an interview with a Western astronaut, talking about memories of her selection, her tone suddenly gets passionate:

[...] we are not yet in a profession where there's a wide variety: people are very, very homogenous. [...] Think about it, what's an astronaut: that's mainly an American or a Russian, [her voice speeds up], that's mainly a man, that's mainly a white guy [...], do you see what I mean? ${ }^{2}$

1 Also cited in Gerovitch, 2015, op. cit., p. 50.

2 [Interview.] NASA 1 (female, North American, has flown several times), realized by phone, 12 July 2016. 
If such features influence the chances to present and to be nominated at a selection, they exercise a certain weight in the socialization to the occupation as well, as long as the training lasts. The above-cited astronaut would have paid a high price for her sex: hazing, exclusion of her peers' group, and defamations aiming to question her ability to fly. The masculine dominion over the astronauts' corps may equal wounds and traumas contributing to the formation of the astronaut habitus, as part of a minority.

Quite the reverse for other women being part of space missions, the training would (aim to) abolish any kind of sex or race distinctions. Since each crewmember remains dependent on his/her crewmates in the realization of demanding tasks and in their safety, and since the trials experienced during the training bond the ones who share them, "being an astronaut" would not be conjugable at the plural form of sexes, races, or even cultures. That is the discourse delivered by Helen Sharman, a British scientist who flew aboard the Mir Soviet space station in 1991 as the first European woman to fly: "when you are an astronaut, you are no more man or woman, those differentiations don't make sense"1.

The boundary distinguishing neutrality and invisibility is tight. Claiming that the belonging to the corps of astronauts or cosmonauts creates sexual neutrality is, in itself, the expression of power relationships among sex. Here is one of the "variations of negation" (Wallace, 2016 [1990], p. 213-240) introduced in the critical analysis of Michele Wallace (to cite only one) in literary criticism: part of the population, including women and furthermore women of color, "cannot be heard, understood, or adequately recognized by dominant mainstream culture" (Wallace, 2016 [1990], p. 9), because this portion of the population is invisibilized through the diffusion of a dominant standardized model of identity, cultural consummation, and social representation. Invisibilized behind a mainstream culture that fits a part of the population presented as a universal model, Afro-American culture becomes in Wallace's terms the "unconscious" of the American History (p. 237).

Moreover, the low number of women in crews detain major consequences on the scientific work that they perform during their flight, while experiments under microgravity conditions represent a third of an astronaut or cosmonaut daily work:

Experiments in microgravity contexts, they have the particularity to require an important number of collected data, especially when it's about physiology. (...)

1 [Fieldwork notebook.] In Saint-Petersburg (Russia), 07 September 2018. 


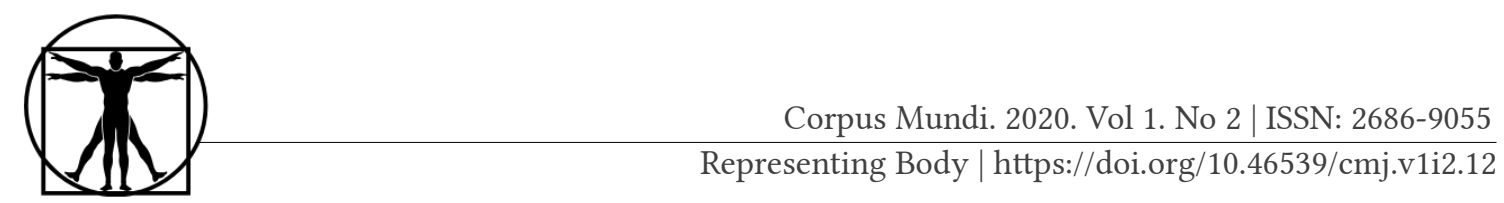

So we always have a number of subjects which... because the difference between men and women on board, on long-duration flights, it's pretty big, right? ${ }^{1}$

Make the marks of sexual particularity disappear is a way to deny its specificity and to impose a dominant model. If some cares reserved to women's bodies, during the training or the flight, may not require other explanations than logistical restrictions, this should not prevent a strong symbolic function. Hence, if the temporary interruption of menstruations during astronauts' flights allows reducing the exponential amount of wastes-which is strictly regulated regarding their mass and the conditions to their elimination-, such manipulation in the intimacy of bodies is an instrument of "discipline" and "docility" (Foucault, 2017) among others, in the process of masculinization which rules the astronauts training.

According to Michel Foucault, "docile bodies" are disciplined through a uniformization of physical appearances, including the shaving of certain parts of bodies, the control of gestures or a complete absence of control over one's own time or space (cf. Foucault, 2017 [1975], p. 166-190). Astronauts are devoid of many means of discipline which are specific to the prison, martial, and school universes analyzed by Foucault. But the abandonment of personal clothes to the benefit of a suit-wearing the space agency logo and the government flag for all public appearance and training session, the hierarchical relationship with instructors surveilling every action of crewmembers, or the delegation of one's schedule to third parties including regarding the management of "personal" or sleep time, are as many tools of the discipline of heroic bodies (p. 166-190). The expression of masculinity takes not only the form of physical strength, rely on embedded values (Wacquant, 2002, p. 234) on behalf of which one will accept institutionalized ordeals.

\section{NORMS AND VALUES: THE TRAINING AS A GENDERED MORAL EDUCATION}

Disciplining bodies and minds remain interrelated, as the military training fairly illustrates: what would be the meaning of the inculcation of physical discipline, without instructing values, moral considerations, and representations that would guide the recruit's course of action? The training thereby contains a "moral and carnal education" taking over a set of corporal and mental schemes so entangled that they fade distinctions between athletic skills (hence the body) and moral abilities (hence the mind) (see Wacquant, 2004).

1 [Interview.] ESA A (female, Western European, has flown several times), realized in Paris (France), 09 November 2015. 
In the moral education of astronauts, the pain in self-realization as a professional astronaut, man, and hero, is central. Pain and physical danger (even minor) remain omnipresent in the daily and routinized work of crewmembers. The case of spacewalks illustrates this feature: being immersed in an environment where temperatures fluctuate between $-200^{\circ} \mathrm{c}$ and $200^{\circ} \mathrm{C}$ against which the spacesuits (fairly flexible and bulky) withstand, working in full sunlight or in complete darkness for six to ten hours continuously, being hoisting from one part of the module to another, taking care to be constantly attached to not being adrift in the void, and demonstrating skills with slightly convenient gloves. Besides dehydration and exhaustion, deep joints and frozen ends, some crewmembers lose some of their nails as their hands are solicited during the activity.

Either in Soviet or Western cultural imaginaries, suffering often evidences the physical and moral superiority of heroes, leading some scholars to argue that heroism, masculinity, and masochism are deeply intertwined (Edwards, 2008), and that endurance of physical pain sets men apart from another in a hierarchy of masculinities (Messner, 1992). While manhood is thus marked by the endurance of physical pain (Jayasena, 2007), the involvement in endurance physical activities is seen as the perpetuation of masculine ideals, even if they may be sometimes injurious: "enduring physical pain is part of what it means to be a man" (Drummond, 2010, p. 201).

Hence, tales of painful trials are quite common in the trajectories of the cosmonauts and astronauts, from isolation in sleep privation to survival training. During an evening with Russian cosmonauts including some of the main directors of the Russian training facilities, I learned myself the detailed process of some of these trials:

Suddenly, the only European astronaut around the table remembers: "you once had an exercise including to not sleep during several days, like what, two, three days?" While he asks the faith of this test, the fact that the Russians tell him that it is still part of the current basic training for candidates cosmonauts shocks him so much that he suddenly put his arms further on the table, and then violently push his back on his chair. While I remain interrogative, two of the Russian cosmonauts explain to me: the candidate is isolated in a room for three days and two nights, with as only rule to not sleep. If one starts to fall asleep, a noisy alarm is put on. The goal of this exercise would be to test the nervous resistance of cosmonauts called to assume the functions of board-engineer and flight commander and to be assured that highly stressful conditions would not lead them to adopt dangerous behaviors (including regarding the hierarchy and the ground support during the flight). The former director of the training center then adds: 


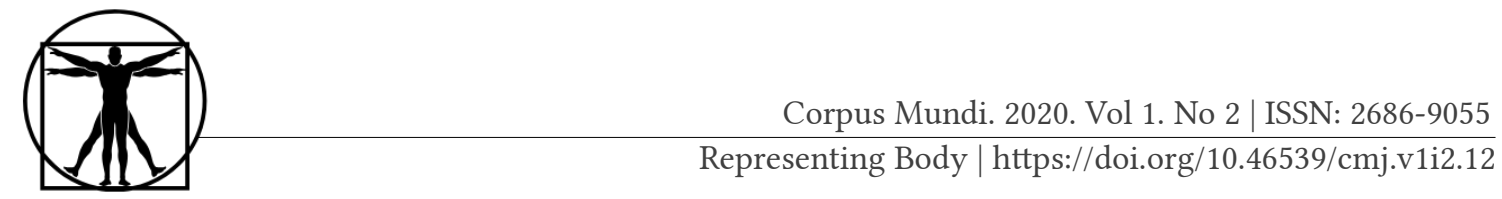

"Anyway it drives you completely crazy, but there are two types of madness: one is good for the flight, the other isn't"1.

While some medical and psychological tests used in the early years of human space exploration were abandoned in Western space agencies, because of their harshness, the Russian space program maintains its methods as they were in the past decades. Such an acceptance of pain is rooted in the history of the Soviet space program and its collective memory. As a Western astronaut suggests in an interview:

[...] to be a hero, in Russia, you have to suffer. You can't be a hero if it's easy, it doesn't work. So, sometimes, you bleed to core out during the survival training, and it could really be done otherwise. [...] But somehow, it is accepted by everyone, because if you go in space, you have to pay: if you want to be a hero, you must have suffered. Otherwise, that's fake ${ }^{2}$.

Moreover, the physical danger and resistance to the pain appear as the condition to let emerge the "right stuff" of what astronaut should be made in preparation for their flight:

One time, there was a case that, in a Soyuz spacecraft in the summer, during a survival training it gets really hot, and from a medical standpoint, it's not so... I don't know... favorable, to have a high temperature in a Soyuz spacecraft during a survival training, you know... You may get dehydrated and eventually, you may die. That's not that bad, but medically it's very important to control the temperature. There were some American astronauts who were saying "yeah, that's true, but at the same time, if you do not put them through this kind of training environment, it's very difficult to understand who he or she is", and that's a true statement ${ }^{3}$.

Hence, the risks are accepted, as well as the awareness of endangering one's bodily integrity. They are accepted because they are seen as traditions, and as some rites of passage which should be respected as part of the physical and moral education. Since every astronaut trains in Russia whatever his/her national belonging, all have to abide by those traditions and rituals shaping the training in Star City. Those trials frame a social bond among crewmembers, whose carnal (by the body) and moral (through the mind) inculcation makes them form a collective body. As important as the values that they are likely to share, the trials through

1 [Fieldwork notebook.] In Toulouse (France), 16 October 2017.

2 [Interview.] ESA R (male, Western European, has flown one time), realized in Mérignac (France), 06 June 2018.

3 [Interview.] JAXA A (male, Japanese, has flown several times), realized in Tsukuba (Japan), 19 November 2017. 
which crewmembers get through and their interdependence in the risk management contribute to forging a certain esprit de corps.

The training is thus simultaneously a moral, emotional, and physical education, leading to the formation and reproduction of a modern hegemonic model of masculinity as one could find similar models in sports, the military, or transnational business (for the latter, see Connell and Wood, 2005). The social theory of heroism highlights how becoming a hero and recognized as such is a political process inherent in gender and social power relationships among sexes (Frisk, 2019). "Masculinity" refers to values as well (such as endurance, courage, bravery, self-discipline, audacity, brotherhood, or even esprit de corps), which are affiliated to masculine attributes and to virility in common sense. Historically, those values are related to a monopoly in the exercise of violence leading men to realize their social identity in the demonstration of physical strength and aggression, and in the obedience to hierarchy as part of self-discipline in the modern military discipline (see among others Foucault, 1988; 2017 [1975]; Higate and Hopton, 2005; Mosse, 1999). Evolved into largely legitimized and disseminated attributes, the ideal figure of the "real man" (a while incarnated in the duelist, the soldier, the gymnast, the adventurer, the "New Soviet Man", the "New fascist man", and the astronaut) sustains political and social stakes, and partly sustained itself through the creation of fantasy "countertypes" (Mosse, 1999). Mainly derived from the military education, where the wearing of uniforms, utilization of weapons, and the manifestation of encounter with danger are the basic instruments of the discipline, virility thus excludes "feminine attributes" (as reified as virile attributes are) which do not fit to a frame where patriarchy is a continuum of colonialism (McClintock, 1995). In a skillful medley of physical and moral properties, the astronaut training as masculinity trial realizes "the man [as] the sex who risks his life and who, in doing so, self-accomplishes" (Haraway, 2007, p. 150), so that the "noble machine" which is the sexualized body fit its aim of virility (p. 187).

Loïc Wacquant provides an analysis of the plural manifestations of masculinity in the social world of boxers in a Chicago ghetto, quite similar to the social world of astronauts: the "flaunting of a masculine corporal capital" does not only take the "explicit form of strength and violence" (Wacquant, 2002, p. 234) but fall within values (endurance, courage, bravery, audacity, esprit de corps), embedded by the individuals taking part in the training. This moral embodiment appears not only as a condition to membership, but primarily a process through which the trainees learn to make sense of their body, self, and environment as incorporated in the manifestation of common representations about masculinity. 


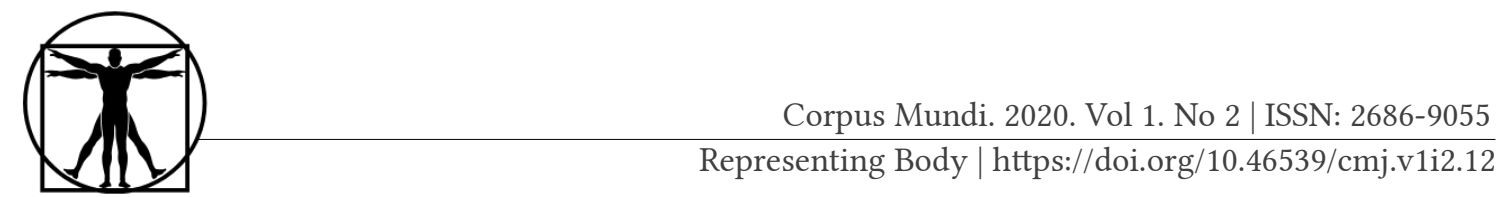

Embedding and expressing those values request institutionalized and codified practices, repeatedly over time. Every community relies on rituals to maintain a sense of the sacred and collective memory, which is necessary for the maintenance of a social order. Thus, rites appear as acts of social magic, maintaining social bonds within a category of individuals. As introduced above, the ritualization structuring the astronaut and cosmonaut training is inherited from the history of the Soviet space program-in particular from the flight of Yuri Gagarin-- and most of these rites are gendered. Each launch has, for instance, to be preceded by the acts and gestures that Yuri Gagarin did before his pioneering flight, on 12 April 1961. This includes stopping on the road while going to the launchpad to urinate on the bus wheel, which may fairly create difficulties for a female astronaut (since 1961, only one took part in this ritual) ${ }^{1}$.

Through these rituals and traditions, bodies reproduce the symbolic conditions of crewmembers' collective identity, which appears to be strongly gendered through action. Those who share the training trials, and playing the game of its rituals, become accomplished as men since they come to share a "virility as spiritual truth" (Haraway, 2007, p. 149). They supported the survival training together, the rotating stools intended to induce them to vomit, the test in the centrifuge and in the hyperbolic chamber, the painful medical examinations; but they also sang the anthem of the Soviet cosmonauts, crossed the halls of the training center in Star City where portraits of the Soviet heroes of the cosmonautic are hanging, stepped up on stairs guided by sculptures of Yuri Gagarin, and when they would take the bus for their last ride to the launch pad, they would stop by the roadside to urinate on a wheel-because that was what Gagarin had done.

Every part of the training is a call to the celebration of virile attributes, from embedded values to the relation with the pain--and as the following section emphasizes, including the standardization used in the selection and the professionalization of crews. Sexualization endorses plural forms, including the denial of sexual distinctions through a uniformization of bodies.

1 Rituals mentioned in this article have been discussed with space historians and crewmembers as part of interviews. Consequently, sources of this section belong to an oral history of spaceflights reconstructed during the fieldwork. Explicit citations of interviewees are avoided to prevent from their identification. For further discussion of these "pre-launch rituals", see Patarin-Jossec, 2018. In the English language, while these rituals are largely discussed in popular culture, critical analysis or exhaustive record in academic literature and space agencies' departments of history (for instance, see NASA History Office, 1976-2000) often overlook this issue, favoring historical records of national space programs. 


\section{BODY STANDARDS: MATERIALIZING MASCULINITY IN THE WORKING ROUTINE}

Endurance regards to pain, mental rigor, discipline, endeavor, fraternity, bravery, courage, or even audacity: all those signs of "carnal rhetoric of honor" (Foucault, 2017 [1975], p. 159) that astronauts embody during their training and which rely upon gendered social representations. The training is precisely a masculinity trial because such tests seek to make bodies "docile" to a set of behaviors proper to a masculine model. This gendered socialization manifests at each step in the professionalization of astronauts. Through this disciplinary process, all astronauts are required to fit the ideal-type of the polyvalent pioneer, likely the ideal figure of the soldier that Michel Foucault assigns to a body language grounded in the virile and proud values of the military habitus (p. 159).

Back in the Soviet Union, the size of cosmonauts was one of the main criteria in the selection, while candidates had to fit with the restricted spacecraft dimensions. To this very day, the selection and the training remain organized according to the same standards, settling scales in tests and evaluations of candidates' capabilities. Exercises of physical endurance, cardiac tests, tests of the vestibular system aiming to measure the resistance to nausea and vertigo, or even criteria involving weight, height, and muscular mass: according to which bodies are those standards elaborated and agreed? That is the central question, as far as there is a uniformization: to the benefit of which/whose body is the plurality of existing bodies lined up, including according to sex and race criteria? Why and how are common norms produced from a particular model of a body? Beyond questioning the raison d'être of such standards, how did a masculine and Caucasian body type, with physiological characteristics generating identity factors which would organize power relationships among sexes and races, become the ground of the astronauts' embodiment?

Since a standard does not exist by itself and is not innate, it is necessarily socially constructed. And since it has to be entirely elaborated, it certainly generates costs ${ }^{1}$. Once edited, a standard aims precisely to save production fees on the required material in the realization of activities for which the standard would have been produced. One of the core mechanisms of the discipline and docile bodies is, indeed, the growth of profit and the search for efficiency. The masculinization of bodies is precisely

1 Asked on these questions of masculine normalization, as part of a documentary about the astronaut selection from a queer perspective, Donna Haraway explains how those costs would appeal to industries able to fund such manufactures of standards, which would lead to analyze sex social relationships within the space field (partly) in terms of industrial lobbying. See Silvia Casalino, « No Gravity », 2011, production 10:15/Perfect Shot film, 61 minutes. 


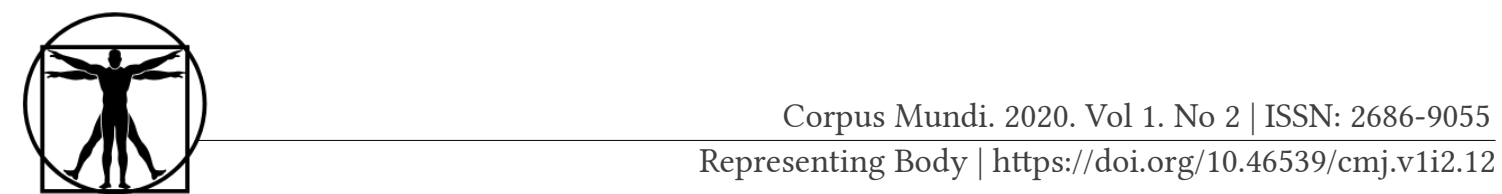

part of the efficiency intended in astronauts' daily tasks and work routine, as illustrated with the example of Russian spacesuits used in extravehicular activities (or "spacewalks", hereafter cited as "EVA").

Two models of spacesuits are used in spacewalks outside the International Space Station: NASA's EMU (Extravehicular Mobility Unit), for any non-Russian crewmember, and the Russian Orlan ("Eagle"), inherited from the Soviet space program. The utilization of the EMU or of the Orlan depends on the segment of the station used for the EVA--i.e. the United States Orbital Segment or the Russian Segment). European astronauts are usually trained with the two spacesuits models, although they shall only use NASA's EMU owing to their belonging to the American segment. When I ask a European astronaut to compare those EMU and Orlan models, the latter confides:

I wouldn't have to have to work on a complicated US task using a Russian spacesuit: that would be very hardworking. You know, the American suits go to a lower pressure, and the gloves, we have 67 sizes of gloves, you can have gloves which are perfectly tailored to our fingers. Russian have 3 sizes of gloves: small, medium and large. There are not so many things you can do in a Russian space suit, in terms of small pieces of equipment. On an American spacesuit, we're rating sometimes with small tools, more sockets, doing detailed work outside the space station ${ }^{1}$.

Russian spacesuits, including gloves and the helmet, are produced in three standardized sizes. If such a standardization certainly allows the save part of the costs involved in the manufacture of tailor-made spacesuits or of a set of sizes as large as astronauts' morphologies require, it nonetheless generates important discriminations among those calls to use them. Conceived on masculine models, any woman who would perform difficult and detailed tasks during an EVA with such a suit would be subject to clumsiness. The inequality among sexes within astronaut and cosmonaut corps is here supported by material conditions, related to the standardization of a masculine body in the manufacture of work instruments. In this respect, an astronaut-who trained in Houston (USA), Köln (Germany) and Star City (Russia)-recounts the case of the last Russian women who flew:

1 [Interview.] ESA K (male, Western European, has flown one time), realized in Mérignac (France), 24 August 2017. 
When Elena Serova was in training, [the director of the training center] was telling the press: "she's hopeless at EVA because she's not tall and strong enough for the helmet" 2 .

This very same former director of the Russian training center would tell me, as part of an interview conducted a few months earlier, that Russians "don't care" about whether a candidate for a job is male or female as long as he/she detains the required qualifications ${ }^{2}$. Nevertheless, if qualifications to become a cosmonaut are based on masculine body standards, one could assume that there is consequently a mechanism of exclusion at the very beginning of the selection process and in the very way the "right stuff" of candidates is imagined. More than a year after (in June 2019) the Russian space agency would cancel an incoming selection of new cosmonauts dedicated to women. As part of the same interview, the European astronaut [ESA R] would draw a comparison up between the Russian case and NASA, where a social context familiar with feminist and interracial struggles remain framed by non-discriminatory policies, making it intolerable to "say at NASA 'we have a helmet, but there are only big guys who can fit in it'. Yet, the normalized use of sizes standardization in Russia, as well as this conception of the individual as supposed to fit the system that he/she uses (rather than the system adapt to individuals) is flawlessly explained by the hermeneutic of Soviet cosmonauts as part of the collective socialist system, mentioned in the first section of the article: as part of a mechanic system, replaceable and disciplined. This hermeneutic, resulting from an ideological system where individuals live for serving the collective, encourages conformity of the plural to a unique effective ideal. Several decades later, while the Russian space program announces a new selection of cosmonauts in 2020, physiological criteria still rely on the idea that cosmonauts' bodies should fit their vehicle and their suits. The dimensions that candidates include in their application are the following: between $50 \mathrm{~kg}$ and $90 \mathrm{~kg}$ (weight); 150-190 cm (height); 80-99 cm (sitting height); $52 \mathrm{~cm}$ (maximum shoulder breadth); 94-112 cm (chest expansion range); $29,5 \mathrm{~cm}$ (maximum foot length).

Nevertheless, masculine standards in the astronaut and cosmonaut embedding process are not restricted to the Soviet and Russian space programs. On 29 March 2019, NASA would have made another leap in spaceflight history, settling the first extravehicular activity ever conducted

2 [Interview.] Roscosmos 1 (male, Russian, has flown several times), realized in Moscow (Russia), 15 May 2017.

2 [Interview.] Roscosmos 1 (male, Russian, has flown several times), realized in Moscow (Russia), 15 May 2017. 


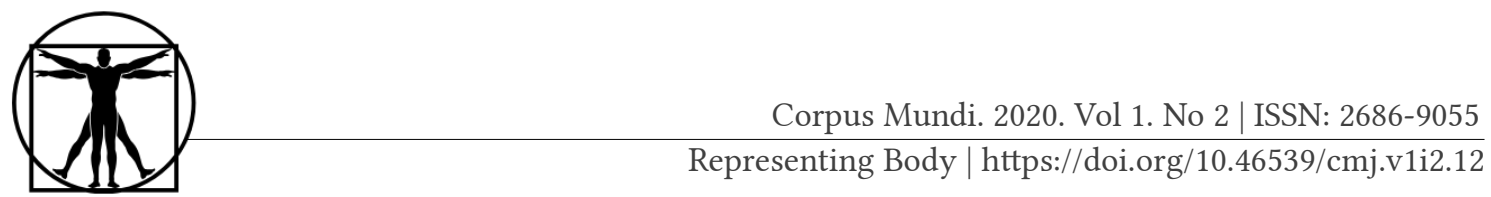

(exclusively) by women-with the U.S. astronauts Anne McClain and Christina Koch. Three days before the EVA, NASA announces that Nick Hague would replace McClain because only one "medium" size spacesuit was prepared. Based on male standards, the US segment contains four spacesuits, including two medium-sized and two larger-the preparation requiring about twelve hours to make it safely configured for a spacewalk.

\section{CONCLUSION}

Despite a lack of scholarly attention to the contemporary astronaut and cosmonaut profession, especially using methods like ethnography, the corporal and moral education involved in the training contributes to a long-standing issue covered in gender theory and body studies emphasizing the use of male bodies and normative values in the standardization of a universal model of identity. In human spaceflight context, this gendered socialization goes through the embodiment of values that contribute to the construction of virile attributes, in addition to relying on the material instruments that masculinize the bodies of women involved in a career of astronaut or cosmonaut-including regarding space suits or medical interventions into bodies' intimacies. The resultant trial of physical and moral endurance, part of the training, creates the illusion that all individual bodies can (and should) become one: that those bodies have neither political, nor sexual or racial boundaries; that they share the same experiences despite the diversity of those individuals made of flesh and gendered socialization, of sensitive bodies experiencing, enduring, and sometimes surpassing themselves. The centrality of physical endurance highlights an ideal human body that would only be conjugated to a masculine singular and emphasizes a model of training which would be identical for all, regardless of gender identities.

Yet, among the rituals, traditions, tests, or embedded values mentioned above, none of the training or in-flight experience appears as gender-neutral, and all of them contribute to the particular manufacture of a heroic body. As Michele Wallace emphasizes, the "invisibilization" of Afro-Americans is, as stated by Ralph Ellison before her (1952), the denial of their presence in the society rather than their physical absence. In a similar dynamic, women are merely physically absent of astronauts' and cosmonauts' corps but furthermore "invisibilized" through the negation of their bodies--in the training, during the flight, and even in the design of spacesuits. As already outlined by Judith Butler (1990), masculinity postulates a normativity constructed against a feminity manufactured as deviation, deficiency, and dearth. If women do not fit the standardized suits tai- 
lored according to an "ideal body", they cannot properly demonstrate efficiency and skills required to be selected and assigned to a flight. If they benefit from less standardized working outfits within Western space programs, they (however) remain subject to a historical narrative of the "space conquest" in which they have been excluded, as discussed in the first section of this article. Their invisibilisation, due to structural mechanisms reproduced through time and space in the spaceflight history, lines with the construction of feminity as a dearth, compared to a complete and fully masculinity used as a reference scale in all the methods used in the process of the professionalization of astronauts.

Because it implies an important training in Russia for international astronauts, the Russian transportation monopoly in human space programs leads to the domination of Russian cultural norms regarding the production of heroes and professional space flyers, regardless of their national belonging. But being a woman in the United States, Japan, France, or Canada is not equivalent to be a woman in Russia. Models of masculinity or any gender identity are not globalized but rather maintain local particularities, and hence require a "nuanced understanding of privileged legitimating conceptions of manhood" (Beasley, 2008). The training of international astronauts in Russia allows a discussion of a masculinity process regarding potential different masculinities in the "global world" versus "nation-State" nexus. Gendered social power relationships depend on gender norms themselves related to local cultural, social, and political contexts. Those norms and the gendered "scripts" of behavior they lead to (Clair, 2016; Gagnon, 2008) require specific attention for how social representations, fantasies, and codes of conduct influence the embodiment process during the astronaut training. Hence, the plural forms of gender norms engaged in the fields of training facilities would likely create distinctions in the experience of astronauts during their training, according to their own previous gender socialization.

However, the fieldwork conducted for this study rather highlights a dominant cultural frame. More than unveiling conditions of coexistence, struggle, or permanency of national models of masculinity in a context of international cooperation, the training in Russia unveils a hierarchy between cultural norms embodied by international astronauts according to their own social and cultural frame of socialization. If the article's argument conflates the U.S., Russian, and European astronaut training, the masculinist culture promoted in the once-Soviet and now-Russian space program prevails for two reasons. First, because all astronauts have to train according to those post-Soviet norms during the lifetime of this transportation monopoly. Second, this training is largely based on sym- 


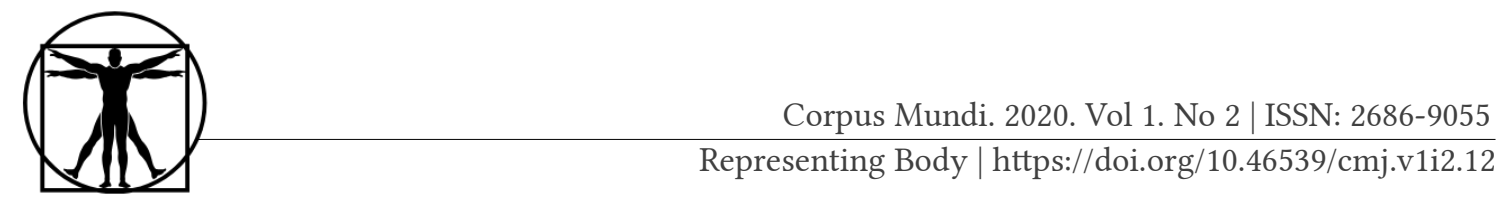

bolic practices (i.e. rituals) which are themselves supported by a model of masculine hero. Either producing acceptance or opposition, this Russian model of masculinity is not without effect. Further analysis would consist of understanding the weight of those norms, accepted during the time of a training in Russia, on the actual identity-building process of international astronauts, and the weight of such a peculiar embodiment on the system of international politics that globally frames human spaceflight.

\section{References}

Beasley, C. (2008). Rethinking Hegemonic Masculinity in a Globalizing World. Men and Masculinities, 11(1), 86-103. Doi: 10.1177/1097 184X08315102

Bergman, J. (1998). Valerii Chkalov: Soviet pilot as New Soviet Man. fournal of contemporary history, 33(1), 135-152. Doi: 10.1177/0 03200949803300108

Boni-Le Goff, I. (2016). Corps légitimes [Legitimate bodies]. In J., Rennes (Eds). Encyclopédie critique du genre [Critical gender encyclopedia] (pp. 159-169). Paris: La Découverte. (in French)

Butler, J. (1990). Gender Trouble: Feminism and the Subversion of Identity. London and New York: Routledge.

Clair, I. (2016). La sexualité dans la relation d'enquête. Décryptage d'un tabou méthodologique [Sexuality in the investigative relationship. Deciphering a methodological taboo]. Revue Française de Sociologie [French Review of Sociology], 1(57), 45-70. Doi: 10.3917/rfs.571.0045 (in French)

Connell, R. (2014). The study of masculinities. Qualitative Research fournal, 14(1), 5-15. Doi: 10.1108/QRJ-03-2014-0006

Connell, R. W. (2005 [1995]). Masculinities (2nd ed.). Oakland: University of California Press.

Connell, R. W. \& Messerschmidt, J. W. (2005). Hegemonic masculinity: rethinking the concept. Gender \& Society, 19(6), 829-859. Doi: 10.1177/0891243205278639

Connell, R. W. \& Wood, J. (2005). Globalization and Business Masculinities. Men and Masculinities, 7(4), 347-364. Doi: 10.1177/1097 184X03 260969

Drummond, M., (2010). Understanding masculinities within the context of men, body image and eating disorders. In B., Gough \&. S., Robertson (Eds.). Men, Masculinities and Health: critical perspectives (pp. 198-215). London, Palgrave MacMillan.

Edwards, T. (2008). Spectacular Pain: Masculinity, Masochism and Men in the Movies. In V., Burr \& J., Hearn, Jeff (Eds.). Sex, Violence and the Body: The Erotics of Wounding (pp. 157-176). Basingstoke: Palgrave Macmillan.

Ellison, R. (1952). Invisible Man. New York: Random House. 
Foucault, M. (1988). L'incorporation de l'hôpital dans la technologie moderne [The Incorporation of the Hospital into Modern Technology]. Hermès [Hermes], 2(2), 30-40. (in French)

Foucault, M. (2017 [1975]). Surveiller et punir: naissance de la prison [Discipline and Punish: The Birth of the Prison]. Paris: Gallimard. (in French)

Fraser, E. (2017). Yuri Gagarin and Celebrity Masculinity in Soviet Culture. In P. E., Muehlenbeck (Ed.). Gender, Sexuality, and the Cold War (pp. 270-289). Nashville: Vanderbilt University Press.

Frisk, K. (2019). What makes a hero? Theorising the social structuring of heroism. Sociology, 53(1), 87-103. Doi: 10.1177/0 038038518764568

Gagnon, J. (2008), Les scripts de la sexualité. Essais sur les origines culturelles du désir [Sexuality scripts. Essays on the cultural origins of desire]. Paris: Payot. (in French)

Gerovitch, S. (2015). Soviet space mythologies. Public images, private memories, and the making of a cultural identity. Pittsburg: University of Pittsburg Press.

Haraway, D. (2007). Manifeste Cyborg et autres essais [Cyborg manifesto and other essays]. Paris: Exils Éditeur. (in French)

Higate, P. \& Hopton, J. (2005). War, militarism, and masculinities. In M. S. Kimmel \& al. Thousand (Eds.). Handbook of studies on men and masculinities (pp. 432-447). Oaks: Sage.

Jayasena, N. (2007). Contested masculinities: Crises in colonial male identity from foseph Conrad to Satyajit Ray. London: Routledge.

Jenks, A. (2012). The Cosmonaut Who Couldn't Stop Smiling: The Life and Legend of Yuri Gagarin. DeKalb: Northern Illinois University Press.

Kamanin, N. (1995-2001). Skrytyi kosmos. Moscow: Infortekst/Novosti Kosmonavtiki.

Lewis, C. (2008). The Red Stuff: A History of the Public and Material Culture of Early Human Spaceflight in the U.S.S.R.. Ph. D. dissertation, History, George Washington University.

Llinares, D. (2008). Contesting the astronaut as a masculine ideal: narratives of myth in Tom Wolfe's The Right Stuff. In Z., Davy and al. (Eds.). Bound and Unbound: Interdisciplinary Approaches to Genders and Sexualities (pp. 76-92). Newcastle: Cambridge Scholars Publishing.

Llinares, D. (2009). Idealized heroes of 'retrotopia': history, identity, and the postmodern in Apollo 13. The Sociological Review, 57(1), 164-177. Doi: 10.1111/j.1467954X.2009.01823.x

Llinares, D. (2011). The astronaut: cultural mythology and idealised masculinity. Newcastle: Cambridge Scholars Publishing.

Markula, P. (2003). The technologies of the self: sport, feminism, and Foucault. Sociology of Sport fournal, 20(2), 87-107. Doi: 10.1123/ssj.20.2.87

McClintock, A. (1995). Imperial Leather: Race, Gender, and Sexuality in the Colonial Contest. New York: Routledge. 


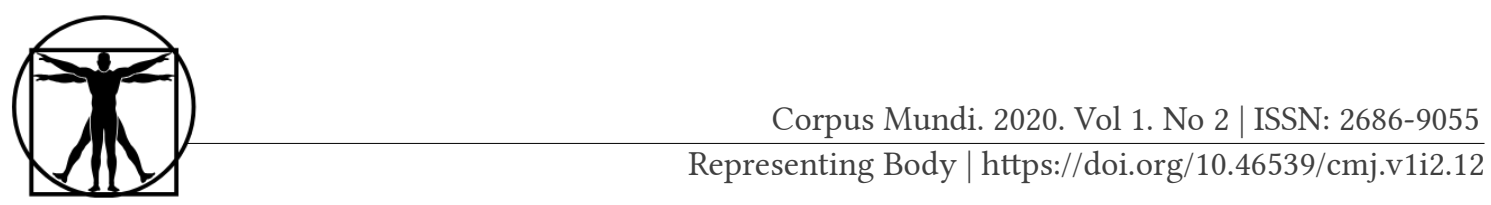

Messerschmidt, J. (2018). Hegemonic masculinity: formulation, reformulation, and amplification. Lanham: Rowman \& Littlefield.

Messner, M. A. (1992). Power at play: Sports and the problem of masculinity. Boston: Beacon.

Mosse, G. L. (1999). L'image de l'homme moderne : l'invention de la virilité moderne [The image of modern man: the invention of modern manhood.]. Paris: Agora. (in French)

NASA History Office. (1976-2000). NASA Historical Data Books (SP-4012), Volume 1-6.

Patarin-Jossec, J. (2018). Le vol habité dans l'économie symbolique de la construction européeenne [Crafting Europe from outer space : human spaceflight in the symbolic economy of the European building]. Doctoral thesis. University of Bordeaux. (in French)

Segal, L. (2008). Gender, war and militarism: making and questioning the links. Feminist Review, 88, 21-35. Doi: 10.1057/palgrave.fr.9400383

Sylvester, R. (2019). "You Are Our Pride and Our Glory!" Emotions, Generation, and the Legacy of Revolution in Women's Letters to Valentina Tereshkova. The Russian Review, 78(3), 392-413. Doi: 10.1111/russ.12237

Wacquant, L. (2002). Corps et âme : Carnet ethnographique d'un apprenti boxeur [Body and soul: Ethnographic notebook of an apprentice boxer]. Paris: Agone. in French)

Wacquant, L. (2004). Body and soul: notebooks of an apprentice boxer. Oxford: Oxford University Press.

Wallace, M. (2016 [1990]). Invisibility Blues. London: Verso.

Список литературы

Beasley, C. (2008). Rethinking Hegemonic Masculinity in a Globalizing World. Men and Masculinities, 11(1), 86-103. Doi: 10.1177/1097 184X08315102

Bergman, J. (1998). Valerii Chkalov: Soviet pilot as New Soviet Man. Fournal of contemporary history, 33(1), 135-152. Doi: 10.1177/0 03200949803300108

Boni-Le Goff, I. (2016). Corps légitimes [Legitimate bodies]. In J., Rennes (Eds). Encyclopédie critique du genre [Critical gender encyclopedia] (pp. 159-169). Paris: La Découverte. (in French)

Butler, J. (1990). Gender Trouble: Feminism and the Subversion of Identity. London and New York: Routledge.

Clair, I. (2016). La sexualité dans la relation d'enquête. Décryptage d'un tabou méthodologique [Sexuality in the investigative relationship. Deciphering a methodological taboo]. Revue Française de Sociologie [French Review of Sociology], 1(57), 45-70. Doi: 10.3917/rfs.571.0045 (in French)

Connell, R. (2014). The study of masculinities. Qualitative Research fournal, 14(1), 5-15.

Doi: 10.1108/QRJ-03-2014-0006 
Connell, R. W. (2005 [1995]). Masculinities (2nd ed.). Oakland: University of California Press.

Connell, R. W. \& Messerschmidt, J. W. (2005). Hegemonic masculinity: rethinking the concept. Gender \& Society, 19(6), 829-859. Doi: 10.1177/0 891243205278639

Connell, R. W. \& Wood, J. (2005). Globalization and Business Masculinities. Men and Masculinities, 7(4), 347-364. Doi: 10.1177/1097 184X03260969

Drummond, M., (2010). Understanding masculinities within the context of men, body image and eating disorders. In B., Gough \&. S., Robertson (Eds.). Men, Masculinities and Health: critical perspectives (pp. 198-215). London, Palgrave MacMillan.

Edwards, T. (2008). Spectacular Pain: Masculinity, Masochism and Men in the Movies. In V., Burr \& J., Hearn, Jeff (Eds.). Sex, Violence and the Body: The Erotics of Wounding (pp. 157-176). Basingstoke: Palgrave Macmillan.

Ellison, R. (1952). Invisible Man. New York: Random House.

Foucault, M. (1988). L'incorporation de l'hôpital dans la technologie moderne [The Incorporation of the Hospital into Modern Technology]. Hermès [Hermes], 2(2), 30-40. (in French)

Foucault, M. (2017 [1975]). Surveiller et punir: naissance de la prison [Discipline and Punish: The Birth of the Prison]. Paris: Gallimard. (in French)

Fraser, E. (2017). Yuri Gagarin and Celebrity Masculinity in Soviet Culture. In P. E., Muehlenbeck (Ed.). Gender, Sexuality, and the Cold War (pp. 270-289). Nashville: Vanderbilt University Press.

Frisk, K. (2019). What makes a hero? Theorising the social structuring of heroism. Sociology, 53(1), 87-103. Doi: 10.1177/0 038038518764568

Gagnon, J. (2008), Les scripts de la sexualité. Essais sur les origines culturelles du désir [Sexuality scripts. Essays on the cultural origins of desire]. Paris: Payot. (in French)

Gerovitch, S. (2015). Soviet space mythologies. Public images, private memories, and the making of a cultural identity. Pittsburg: University of Pittsburg Press.

Haraway, D. (2007). Manifeste Cyborg et autres essais [Cyborg manifesto and other essays]. Paris: Exils Éditeur. (in French)

Higate, P. \& Hopton, J. (2005). War, militarism, and masculinities. In M. S. Kimmel \& al. Thousand (Eds.). Handbook of studies on men and masculinities (pp. 432-447). Oaks: Sage.

Jayasena, N. (2007). Contested masculinities: Crises in colonial male identity from foseph Conrad to Satyajit Ray. London: Routledge.

Jenks, A. (2012). The Cosmonaut Who Couldn't Stop Smiling: The Life and Legend of Yuri Gagarin. DeKalb: Northern Illinois University Press.

Kamanin, N. (1995-2001). Skrytyi kosmos. Moscow: Infortekst/Novosti Kosmonavtiki. 


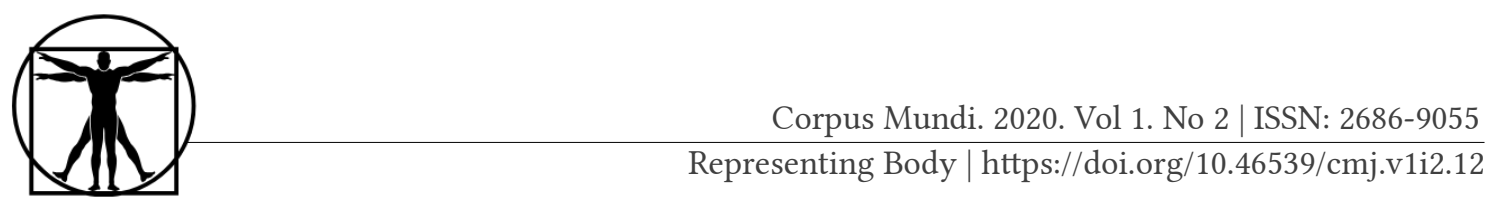

Lewis, C. (2008). The Red Stuff: A History of the Public and Material Culture of Early Human Spaceflight in the U.S.S.R.. Ph. D. dissertation, History, George Washington University.

Llinares, D. (2008). Contesting the astronaut as a masculine ideal: narratives of myth in Tom Wolfe's The Right Stuff. In Z., Davy and al. (Eds.). Bound and Unbound: Interdisciplinary Approaches to Genders and Sexualities (pp. 76-92). Newcastle: Cambridge Scholars Publishing.

Llinares, D. (2009). Idealized heroes of 'retrotopia': history, identity, and the postmodern in Apollo 13. The Sociological Review, 57(1), 164-177. Doi: 10.1111/j.1467954X.2009.01823.X

Llinares, D. (2011). The astronaut: cultural mythology and idealised masculinity. Newcastle: Cambridge Scholars Publishing.

Markula, P. (2003). The technologies of the self: sport, feminism, and Foucault. Sociology of Sport fournal, 20(2), 87-107. Doi: 10.1123/ssj.20.2.87

McClintock, A. (1995). Imperial Leather: Race, Gender, and Sexuality in the Colonial Contest. New York: Routledge.

Messerschmidt, J. (2018). Hegemonic masculinity: formulation, reformulation, and amplification. Lanham: Rowman \& Littlefield.

Messner, M. A. (1992). Power at play: Sports and the problem of masculinity. Boston: Beacon.

Mosse, G. L. (1999). L'image de l'homme moderne : l'invention de la virilité moderne [The image of modern man: the invention of modern manhood.]. Paris: Agora. (in French)

NASA History Office. (1976-2000). NASA Historical Data Books (SP-4012), Volume 1-6.

Patarin-Jossec, J. (2018). Le vol habité dans l'économie symbolique de la construction européeenne [Crafting Europe from outer space : human spaceflight in the symbolic economy of the European building]. Doctoral thesis. University of Bordeaux. (in French)

Segal, L. (2008). Gender, war and militarism: making and questioning the links. Feminist Review, 88, 21-35. Doi: 10.1057/palgrave.fr.9400383

Sylvester, R. (2019). "You Are Our Pride and Our Glory!" Emotions, Generation, and the Legacy of Revolution in Women's Letters to Valentina Tereshkova. The Russian Review, 78(3), 392-413. Doi: 10.1111/russ.12237

Wacquant, L. (2002). Corps et âme : Carnet ethnographique d'un apprenti boxeur [Body and soul: Ethnographic notebook of an apprentice boxer]. Paris: Agone. in French)

Wacquant, L. (2004). Body and soul: notebooks of an apprentice boxer. Oxford: Oxford University Press.

Wallace, M. (2016 [1990]). Invisibility Blues. London: Verso. 